\title{
Informational support for families of children with autism spectrum disorder
}

\author{
Apoio informacional às famílias de crianças com transtorno do espectro autista \\ Apoyo informativo para familias de niños con transtorno del espectro autista
}

\author{
Gisele Weissheimer ${ }^{a}$ \\ Verônica de Azevedo Mazza ${ }^{a}$ \\ Cibelly Aliny Siqueira Lima Freitas ${ }^{\mathrm{b}}$ \\ Silvana Rodrigues da Silvac
}

\section{How to cite this article:}

Weissheimer G, Mazza VA, Freitas

CASL, Silva SR. Informational support for families of children with autism spectrum disorder. Rev Gaúcha Enferm. 2021;42:e20200076. doi: https://doi. org/10.1590/1983-1447.2021.20200076 a Universidade Federal do Paraná (UFPR). Curitiba, Paraná, Brasil.

${ }^{b}$ Universidade do Vale do Acaraú (UVA). Sobral, Ceará, Brasil.

c Universidade Federal do Amapá (UFAP). Macapá, Amapá, Brasil.

\section{ABSTRACT}

Objective: To identify the sources of informational support used by families of children with Autism Spectrum Disorder.

Method: Qualitative and descriptive research carried out in three health institutions and three teaching institutions in Paraná, Ceará and Amapá. 55 family members participated who responded to semi-structured interviews, between September 2018 and 2019. Thematic categorical analysis and the resources of Qualitative Data Analysis Software were used.

Results: Families find informational support from several sources, both formal and informal, such as the internet and other sources (books, Workshops, courses, television).

Conclusion: Families use different sources of information, however, often incomplete and contradictory, which can generate a new demand on health professionals, in order to integrate access to information in the health care process, since they must be considering benefits and weaknesses that this represents for society.

Keywords: Autistic disorder. Internet access. Access to information. Social support.

\section{RESUMO}

Objetivo: Identificar as fontes de apoio informacional utilizadas por famílias de crianças com Transtorno do Espectro Autista.

Método: Pesquisa qualitativa e descritiva, realizada em três instituições de saúde e três de ensino no Paraná, Ceará e Amapá. Participaram 55 familiares que responderam a entrevistas semiestruturadas, entre setembro de 2018 e 2019. Utilizaram-se análise categorial temática e os recursos do Qualitative Data Analysis Software.

Resultados: As famílias encontram apoio informacional em diversas fontes, tanto formal quanto informal, como internet, entre outras (livros, Workshops, cursos, televisão).

Conclusão: As famílias utilizam diferentes fontes de informação, porém muitas vezes incompletas e contraditórias, as quais podem geram uma nova demanda aos profissionais de saúde, de forma a integrar o acesso às informações, no processo de cuidar em saúde, uma vez que devem ser considerados os benefícios e as fragilidades que isso representa para sociedade.

Palavras-chave: Transtorno autístico. Acesso à Internet. Acesso à informação. Apoio social.

\section{RESUMEN}

Objetivo: Identificar las fuentes de apoyo informativo utilizado por familias de niños con trastorno del espectro autista.

Método: Investigación cualitativa y descriptiva realizada en tres instituciones de salud y tres instituciones de enseñanza en Paraná, Ceará y Amapá. Participaron 55 miembros de la familia que respondieron a entrevistas semiestructuradas, entre septiembre de 2018 y 2019. Se utilizó el análisis categórico temático y los recursos del Qualitative Data Analysis Software.

Resultados: Las familias encuentran apoyo informativo en diversas fuentes, tanto formales como informales, como en internet y otras fuentes (libros, talleres de trabajo, cursos, televisión).

Conclusión: Las familias utilizan diferentes fuentes de información, pero muchas veces incompletas y contradictorias, lo que puede generar una nueva demanda de profesionales de la salud para integrar el acceso a la información en el proceso de atención de la salud, ya que deben ser considerado los beneficios y debilidades que esto representa para la sociedad. Palabras clave: Transtorno autístico. Acceso a Internet. Acceso a la información. Apoyo social. 


\section{口INTRODUCTION}

Estimates show that for every 1,000 children with 8 years old 17 are affected by Autism Spectrum Disorder (ASD)(1). This is characterized by changes in children's brain development that affect communication, the relationship with people and behavior. The child has interests in unusual activities, repetitive behaviors and has altered sensory behaviors ${ }^{(2)}$. This makes families to face many challenges and need social support for child care ${ }^{(3)}$.

There are different means of social support, didactically classified as emotional, self-assessment, instrumental and informational. The emotional refers to the feeling of esteem and belonging, perceived by the individual through receiving affection, empathy, love and trust. Self-assessment refers to the provision of relevant information for the assessment itself. The instrumental is the offer of support in terms of goods and services, such as help with daily tasks, financial support, care for children, the home, among others ${ }^{(4)}$.

Informational support is the provision of information to a person to help them deal with personal issues and problems in their daily lives. The main groups, institutions or individuals that can provide social support are family members, co-workers, people who provide services to a family, mutual aid groups, health professionals, social workers, among others ${ }^{(4)}$.

These groups and people compose the support network for families, which can be classified into formal and informal support networks. The first is characterized by the state and private service systems that serve the community, such as health institutions, government programs, social assistance services, professionals who assist families, among others. The second corresponds to networks made up of individuals, such as the child's own family members, friends, neighbors and social groups, for example, clubs, associations, churches, among others ${ }^{(5)}$.

These social support networks are important to the families of children with ASD to help them deal with the demands of the disorder in their daily lives and develop strategies to face them ${ }^{(6)}$. In a study carried out in Canada, with 143 families, it was found that $94 \%$ needed information support; $90 \%$, professional support; $89 \%$, of family and social support; $87 \%$, of financial support; $75 \%$, help to explain to others about ASD; and 69\% needed help in finding schools ${ }^{(7)}$.

Studies on social support for this public have been developed from the perspective of emotional, instrumental support and, less frequently, informational support ${ }^{(6,8)}$. The provision of information is inherent to professional practice in the health field, however families report difficulties in accessing it. In addition, in recent years, there are other sources that have been used as mass media(9).

The complex nature of ASD and the controversies related to its etiology and treatment often represent, for parents, a source of imprecision and ambiguity in understanding the disorder after the establishment of a formal diagnosis by a professional ${ }^{(10)}$, frequently, parents do not obtain information they consider sufficient and, therefore, continue to seek it to provide quality of life for the child and the family(9).

In this context, they ask themselves: what are the informational networks used by family members of children with autism to answer their doubts? Timely information is important for facing the disorder. Knowing the sources of information accessed by families that demand support needs means mobilizing resources so that it is possible to help them. Therefore, providing support for health professionals and managers to participate in the information support process that promotes effective support for promoting the child development of children with ASD. Thus, the aim of this study was to identify the sources of informational support used by families of children with Autism Spectrum Disorder.

\section{METHODOLOGY}

This is a qualitative, descriptive, multicenter research, carried out in three cities in three states in Brazil: Paraná, Ceará and Amapá. In Paraná, it took place at the Association of Parents Friends of the Exceptionals (Associação dos Pais Amigos dos Excepcionais - APAE) and at the Neuropediatrics Center (Centro de Neuropediatria - CNP). APAE aims at the education, health, and social assistance of children, with professionals who comply with these three demands. CNP is a public institution that integrates neurological specialty clinics, has a multidisciplinary team, and provides care through the Unified Health System (Sistema Único de Saúde).

In Ceará, the research was carried out in three locations: at APAE, at the Psychosocial Care Center (Centro de Atenção Psicossocial - CAPS) and at the Rehabilitation Center (Centro de Reabilitação - CR). APAE is made up of parents and friends from a community of students with special needs. CAPS serve people with mental disorders and develops family and community integration activities. The CR serves people with special health needs, who need physiotherapy, speech therapy, occupational therapy, social work, medical and nursing.

In Amapá, research was carried out at a Children's Educational Center (Centro Educacional Infantil - CEI), a public institution, linked to the State Government, which provides care to people with genetic and neurological disorders. In addition, it offers specialized pedagogical and clinical services. 
The invitation to participate in the study to family members was made on the day they were accompanying the child in consultation or in educational institutions. It was made a survey of children who fit the age group sought and, afterwards, an invitation was made to their family members. Data collection took place over 12 months, starting in September 2018. Participants were 55 family members of children with ASD. The inclusion criteria were being a family member of an autistic child aged 4 to 10 years old, living in the same house and providing care for her. Exclusion criteria were being a minor and family member of an autistic adolescent.

The selection of family members of children aged 4 to 10 years is justified because the literature ${ }^{(1)}$ shows that the diagnosis of ASD has occurred around 3 to 4 years. In this context, the assertiveness in the selection of family members for this study would be greater. Family members of adolescents were excluded, since their information needs are different from family members of children, as this is a school/educational phase different from that of children, involving issues related to vocational education, independence in daily life, sexuality, among others. Thereby, they can seek other sources of information. It was considered the family member who performed care for the child by the experience and the need to search for information from different sources to perform this task.

21 interviews were realized in Paraná ( 5 at APAE and 16 at CNP), 22 in Ceará ( 6 at APAE, 2 at CAPS and 14 at CR) and 12 in Amapá (CEI). It was semi-structured individual interviews, using an instrument with variables to characterize the family member (age, gender, marital status, years of study, kinship with the child and family income) and the child with ASD (age, time living with ASD, gender and educational bond). The introductory question for the interviews was: "How has it been for you to have a child with ASD in your family?".

The interviews were conducted in a private room, at each data collection location, lasted an average of 20 minutes, were recorded and later transcribed. Previously, pilot interviews were conducted to adjust the data collection instrument. After this phase, some questions were readjusted in order to present them more appropriately for the purposes of the research. The interviews were conducted in a private place. The sample was intentional and defined by data saturation, when it reaches the objectives and the understanding of the studied phenomenon.

The contents of the interviews were revised in relation to spelling, without changing the essence. For example, language addictions, such as "ok", have been replaced for its right, "was" for it was and so on. For operationalization and analysis of the interviews, it was used thematic categorical analysis ${ }^{(11)}$ regarding the organization, reading, preparation and coding of data. These were distributed in blocks or segments of text; groupings into categories, which were established based on the similarity between the sentences found.

Qualitative Data Analysis Software resources were used to categorize the content. The researcher interpreted the words and phrases of the textual corpus and, from that, clippings of the registration units were made, constituting the codes, which were categorized, called tree codes.

To guarantee the confidentiality of the data and the anonymity of the participants, the identification was replaced by a number sequence from 1 to 55 . Access to the data is restricted to researchers. This research was approved by the Research Ethics Committee, under Statement No.2,327,633, on October 11, 2017, CAEE 73197617.0.1001.0102. The standards recommended by Resolution No. 466/12 of the National Health Council were attended. The interviewees received and signed the Free and Informed Consent Form, in two copies, to confirm the acceptance of participation in the study, as well as the guarantee of anonymity.

\section{RESULTS}

The average age of the participating family members was 37 years old, minimum 25 years old and maximum 52 years old. Most were mothers of children with ASD, as shown in Table 1.

Characterization data for children with ASD showed an average age of 6.3 years, $15 \%(n=8)$ were up to 5 years old and $85 \%(n=47)$ from 6 to 10 years old. Table 2 shows that, predominantly, they were male and were studying.

Were obtained as a result, four categories of source of informational social support: formal source, informal source, internet and other sources. 21 codes were obtained from the internet, 22 from other sources, 23 from the informal and 62 codes from the formal source.

In the first category, formal sources, it was identified that families receive information from several professionals, as in the health, social assistance and education areas. Such information refers to the disorder, how to manage the sensory and behavioral changes generated by ASD, about the rights of children and information required by families:

It was the social worker, from the rehabilitation center, who guided me, because I "didn't understand", I "didn't know" anything about autism (34).

I seek [mother] information mainly from doctors, specialists (9).

So we receive guidance in the services and the guidelines are about how we have to treat, how to speak, how to deal, how to respond, from the professionals who work in this area (50). 
Weissheimer G, Mazza VA, Freitas CASL, Silva SR

Table 1 - Characterization of participants ( $n=55)$. Curitiba, Brazil, 2019

Variables

\section{Gender}

Female

$52(95)$

Male

\section{Marital status}

Married

$26(47)$

Stable union

$13(24)$

Divorced

Widow

Single

Years of studies

5 to 8 years

9 to 11 years

$25(45)$

12 to 16 years

$21(38)$

Did not answer

$1(2)$

\section{Kinship with the child}

Mother

$48(87)$

Father

Grandmother/Grandfather

Sister

\section{Family income}

Not reported

Up to $R \$ 500,00$

$R \$ 501,00-R \$ 1.000,00$

$10(18)$

$R \$ 1.001,00-R \$ 1.500,00$

$11(20)$

$R \$ 1.501,00-R \$ 2.000,00$

$R \$ 2.001,00-R \$ 2.501,00$

9 (16)

$>\mathrm{R} \$ 2.501,00$

$9(16)$ 
Table 2 - Characterization of children with ASD ( $n=55)$. Curitiba, Brazil, 2019

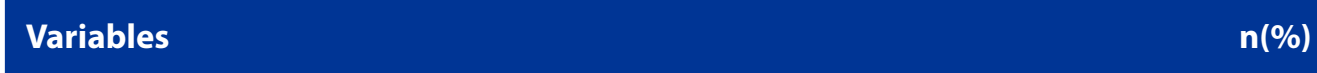

\section{Time living with the disorder}

Up to 1 year

$2-3$ years

$4-5$ years

$6-7$ years

There is no report/diagnosis
$15(27)$

$16(29)$

$14(25)$

$3(5)$

$38(69)$

Male

Yes

$1(2)$

Source: Study data, 2019.

They [APAE professionals] taught me how to take care, how to understand, how to give food, how to learn to use the bathroom. And all of this we have been achieving over time (28).

The one who guided [to do the therapies] immediately was the neuropediatrician, look, you have to do a speech therapist, occupational therapist, psychologist (50).

Here [Educational Center] there is always a short course, some information to update us (55).

As soon as we enroll, they [professionals] already inform us [about the public transport provided] (28).

Who guided the rights in the PSF [Family Health Program] was the nurse and the doctor (35).

At the [service center] they [professionals] gave all the information and since then we looked for them, they already have this right of exemption (11).

It is noteworthy, in some reports, that families perceived limitations of formal sources, such as the lack of knowledge in relation to ASD, which interferes in the diagnosis process and in the insufficiency or lack of provision of guidance:

Even the psychologist didn't know how to deal, because as I told, not everyone has this specialization, this knowledge (50).

With one and a halfyear he started talking, then he started to get out of diaper, when he turned 2 he regressed, he stopped talking and went back to diaper. That's why I went to the pediatrician, but she said that each child has their time, so I thought she was right (8).

I think it is poor the issue of autism both because of the lack of professional and research (50).

Nobody advised me about rights (41).

All the information I have today is because I researched it, because no one gave information. All places are very vague, both prepared and unprepared, I had to do research, if not, I wouldn't understand him (10). 
And I think we should have more people [professionals] trained so that we know how to deal better with what is really right, what is wrong about autism (41).

I would like to have [...] better clarification on the part of people, I would like to have a welcome, I wish it would be easier for you to get help for the autistic person (10).

I think there is a need for greater support from the government, not only in therapies, but sometimes even help in knowledge for parents, to have this greater support from the government (19).

Sometimes we are helpless, and I do research (45).

In the second category, the informal source, information was obtained from other families of children with ASD, associations and Non-Governmental Organizations (NGOs), in which information exchange takes place by different means, such as in meetings where children receive care by blogs and WhatsApp. The information shared covered the disorder, the choice of therapy and its efficiency, indications of professionals to care for the child and how to obtain the rights to government subsidies:

She [mother of another child with ASD] went through everything you can imagine, types of therapists, therapies and everything. She already broke her face, so she says: this works, this does not work. She who indicated these therapists that she [the child] is today and thank God were very good indications (19).

Where I arrived was told that such a place has a professional for autistic people, I went. There is a psychologist for autism, I went. So, each information they [family members of other children] gave me was good for me as well as for him [child with ASD] (22).

I talk to other mothers to see if they have been through this situation that I am going through (31).

[...] the cool thing is that here [the child care center] we get to know other parents, they tell us what they do, look at such place there are professionals like that, talk about how we have to obtain things (50).

We get information by seconds, third parties (40).

I met mothers of other children over the internet. It's a blog, like a website (9).

In fact, I participate in groups of parents, on WhatsApp, from all over Brazil, so there is a lot of information there (8).

The informal sources related to the Associations and NGOs were also represented in the participants' reports:
I participate in the group [name], the girls post all the information there, so, in fact, what helps me the most is the group, all the information about autism, video and lecture (13).

He [child with ASD] was accompanied by [name of association]. This association provided support (information) for people, but I, individually, tried to find out several things about his rights [child], reading ... these things (22).

In my city there is an NGO, which I helped to create and here in (city) I participate in [name of the NGO], so there are always lectures during the year (6).

It was in a conversation at a mom's club that I learned about his rights [child]. So, they were talking and I asked if the [child] had right and they [mothers] said yes, he is autistic, he has a right, then the priorities came up for him, what he was entitled to or not (19).

In the [name of the association] it is more distant, I saw the need for transportation, so l looked with other mothers who live more distant to be able to move, then they told me that they have the right to this card (30).

As seen in the reports, mothers acquire knowledge regarding autism and become sources of information for other people. In addition to the sources mentioned above, family members use the internet to find out about unknown symptoms, the disorder and the rights of children:

I knew there was something wrong with my son, I didn't know what it was. Mother is curious, I put her symptoms on the internet, it fell into autism (53).

There is a page on the internet about autism, there is all the information, then what you don't have there, you get it and put it on Google, because it's the only way (10).

After the diagnosis I found myself lost without knowing what to do. Then we started to have a north to chase, I researched a lot on the internet, I read many articles, I read many books, everything I could know about autism I went after to help my son (47).

I watch lives, the (professional) is a specialist in autism, I see the (name of the professional), but one thing is that you are seeing there, then you will try to do (5).

About what they (children) have right to, I always research on the internet (26).

We read about Law 11.112, exemption from IPVA. It is published on the internet. And researching the rights of 
children with disabilities, we ended up seeing which one fit for us, and we used it (1).

That they (children) have right, I always research on the internet. I always search the internet for what I know, both from one thing to the other (34).

As verified, the internet is a form of support, family members have autonomy to seek what they need. Despite this, they reported some negative aspects, such as confusing, unsafe information, and about drug reactions in the individual. Thus, the access to a large amount of information, without professional support, brings insecurity and fear to families:

There is not much half-term, on the internet you have to know how to select a little, because if not, you start freaking out, there is a lot of confusing information (6). I already read some things about autism, but like that, there are a lot of things that we learn and there are times that if we are like, if we go to read everything we see (23).

I was reading some things about this medication, I was scared, what I read, which was addiction, then it was like an impregnation (42).

There are many things on the internet, but we don't know what is right, what is wrong (41).

The fourth category, other sources of information, are books, courses and TV. These sources were provided by family members and friends of the parents of the child with autism to support them:

Book, l earned some. Family and friends discover that we have this problem and end up giving books about it. I mainly use books (1).

Whenever there is a book I buy, I already have a good collection (6).

I took [mother] several courses on autism, including undergraduate, which I am studying (46).

I [mother] participate a lot in lectures, so, always in the lectures they end up talking about some things, about some benefits that we have (6).

I always watch programs on television when it shows, the rights he has (26).

I've researched almost everything. I already went after it, buy a video, watch [name of the presenter], who shows these things a lot and I just watch (25).

(After the diagnosis) I (mother) saw me lost without knowing what to do, then we started to have a north, I searched a lot on the internet, I read many articles, I read many books, everything I could know about autism I went after to help my son really (47).

As seen in the speeches, the information accessed refers to the disorder, child behavior and the family's perception of promoting quality of life for the child.

The following report shows how much families are empowered from the information they access:

[...] today lam no longer so curious about autism, because you know, when we have a child, who has this problem, we specialize (34).

Families take ownership of the knowledge of different sources of information and become sources of information.

\section{DISCUSSION}

Informational social support is an important resource for families of children with $\mathrm{ASD}^{(8)}$. As seen in the results of the present study, people have access to information from different sources. Previously, professionals were the main reference for information and guidance, currently they remain, however they are not the only ones. The continuity of the search for professionals is demonstrated by the number of codes analyzed. The formal source of support was mentioned most frequently by the families, and then the other sources.

Professionals have an important role in providing information to families during the diagnosis of childhood ASD and in following the disorder to assist them in making decisions ${ }^{(12)}$. In agreement with other studies, the formal sources of support were pediatric neurologists ${ }^{(3)}$, teachers, therapists ${ }^{(13)}$, social worker ${ }^{(14)}$, among others.

On the other hand, there is a limitation in the experience and knowledge of some professionals in relation to ASD. There are not always professionals and specialized institutions close to families that need this type of care $^{(7)}$. In addition, there is a lack of standardization as to the procedures adopted in the different services ${ }^{(3)}$.

The limitations in care generate dissatisfaction and stress for families, representing a barrier for parents in coping with this condition. This makes them to take their child to different professionals to assess changes in child development ${ }^{(3)}$. Generally, families dissatisfied with the information process in their child's diagnosis are unlikely to seek support from professionals again ${ }^{(8)}$. These data show the importance of governmental measures to qualify services and professionals to meet the information demands of family members of 
children with ASD. However, the working conditions of the professionals, such as the workload, the number of professionals available for assistance, the number of patients to receive care, the bond, among others, need to be investigated to explore the existing limitations.

Besides the formal support, families seek informal sources, such as family members of other children with $\mathrm{ASD}^{(9-10)}$. Soon, they constitute an important support network for parents to be aware that they are not alone, that there are other people to share the same situation ${ }^{(14-15)}$. According to the present study, contact between parents is not limited to people from the same geographic region, such a reduction in distances and variety of informational resources is due to the use of the internet, which allows the use of social networks, such as WhatsApp and blogs, which allow contact and exchange of information between people from different cities and countries. Thus, technology is a tool that helps families to exchange mutual support. This support is important because it makes it possible to share information about services that provide diagnosis ${ }^{(10)}$, professionals who have experience in the area ${ }^{(10,16)}$, service and intervention providers ${ }^{(10)}$, clarifications about networks and social services and institutions of community support for child with ASD ${ }^{(14)}$.

The families have support groups, associations and NGOs formed by parents and/or professionals who work for families and children with ASD, which are important sources of information, given that sharing contributes to the knowledge of their rights, of caring, behavior management or other previously unknown opportunities ${ }^{(10)}$. The associations organize workshops, courses and seminars to help parents with information about their own disorder and services to assist children with $\mathrm{ASD}^{(14)}$. This shows a change of scenario, because, previously, the user of this type of service was professionals and nowadays it is also family members, thus, there is a greater role of parents in the search for knowledge of the child's condition and a differentiated form of support from NGOs.

In addition to the sources mentioned above, the internet was a source used to obtain informational social support. A study from another country has shown that the use of the internet and social media should be considered relevant for professionals who work with families, as long as the informational support in the online environment is properly structured, it can be a source of support for health needs of the families ${ }^{(17)}$. In this way, it is possible to verify that in Brazil there is a need to rethink the professional practice in order to make more flexible the insertion of some informational resources in health care. However, such resources must be developed by qualified people and in a format designed for this population. However, for this, efforts are necessary from several government agencies so that it is well structured.

It should be considered that not all families have an education level to interpret technical information in secure sources in the online environment, such as in scientific databases. Therefore, it is not enough to simply instruct them to seek reliable information.

Therefore, it is important to guide family members regarding the reliability of the content freely available on the internet, as they are not always scientifically based ${ }^{(18)}$. In addition, it must be considered that many families in an unfavorable socioeconomic condition may become vulnerable in the face of insecure information, since they may not know how to evaluate them. Thus, it is considered important to explore in future studies, with professionals and managers, the possibility of developing secure informational resources in different formats that are accessible to families.

This is relevant because other researchers have shown that the information obtained online is often used to guide decisions about the child's health, even before obtaining a formal assessment. Furthermore, the use of information obtained on the internet has influenced people's lives, so that many were not surprised by the diagnosis of ASD because they used online resources before seeking diagnosis(3).

On the other hand, it turns out that families use the internet to clarify aspects that are not understood, reduce anxiety, establish a form of communication with professionals and know how to position themselves in relation to the adopted therapeutic approaches ${ }^{(18)}$. Another study suggested the use of the internet as a strategy to obtain knowledge to address the lack of support received from formal sources ${ }^{(6)}$. Family members would like to receive clearer information, in a reserved place, with more time for professionals to explain doubts and the technical terms used ${ }^{(18)}$.

In this study, families cited obtaining information from formal and informal sources. Even with the limitations mentioned in the formal sources, it cannot be stated that the use of the internet occurs due to the lack of formal support, since it can be used simultaneously due to free access ${ }^{(17)}$. Despite the easy access, such a search can generate risk for the patient in situations where it replaces the conduct of a professional ${ }^{(3)}$. Despite the lack of training in some cases, the information available in the online environment does not exclude the need for the evaluation of a professional who is qualified to assist people with ASD.

Another way of use of the internet among families is through social media, in order to enable them to share stories, similar experiences and information. People can connect to each other through online networks, such as Facebook, 
Twitter, Instagram, blogs, among others ${ }^{(19)}$. This increase in connectivity has been beneficial for many people, in terms of access to information. However, the families themselves recognize negative aspects, such as lack of quality of information ${ }^{(20)}$, excess, imprecision ${ }^{(12)}$ and less attractive data ${ }^{(18)}$, such as the negative effects of medication use reported in this study.

This creates a concern, since, on the one hand, families can be well informed, on the other hand, access to low-quality information can take them to the risk of making wrong decisions $^{(12)}$. Similarly, other studies show that families use other resources, such as books ${ }^{(9)}$, lectures, workshops, videos ${ }^{(14)}$, courses and specializations $s^{(6)}$. These data were corroborated by the participants of this research when they claimed to have received informational support indirectly from family and friends through books about ASD. This is certainly due to the still limited knowledge about autism in the community in genera|(6), so family members provide support in other ways.

Parents use videos available on YouTube to learn how to intervene and care for their child, for example, ways to help progress in speech, attention or motor skills $s^{(3)}$. This creates an unquietness with regard to the security of the available content, as there is the possibility of uploading video to YouTube by any user, however there is no quality control of the content. On the other hand, it can be a very useful tool, as long as it contains credible content. Studies show that there is a variety of videos made by health professionals, with useful and reliable information for families ${ }^{(19)}$.

In other countries, such as Canada, professionals have been working with social media on health-related issues, for example, podcasts are a popular and useful form of content sharing. A podcast or vodcast can be downloaded on a cell phone or iPod, and then people can listen while performing other activities of daily living ${ }^{(19)}$. These strategies can be used in health promotion or even for families with children who have chronic diseases or disorders that make it difficult for parents to leave their homes. However, this is a new demand for professionals who work with this audience.

As verified in this study, there are different sources of information accessed by families. What can be shown through these results is the movement of change generated by the technologies. This causes society, especially health professionals, to develop strategies with health managers to manage these demands so that, in addition to meeting the families' information needs, they provide safe resources for families ${ }^{(18)}$.

The access to sources of information assists in family knowledge and empowerment to manage the demands of the disorder and to maintain effective communication with professionals about the conduct taken in view of the children's health situation ${ }^{(5)}$. Knowledge generates a change in behavior, which makes the family member a participant in the children's therapy ${ }^{(18)}$.

The knowledge of families and the sources accessed provide support for decision-making regarding child health ${ }^{(3)}$. However, in addition to knowing the sources of information accessed, there is a need for a better understanding of how parents are using information from different sources to be able to help them to create strategies so that they can critically examine the credibility of the information. Thus, new studies are recommended to explore this issue.

It is suggested that future studies explore access to different sources of information, according to the social and economic status of families, as it believes that this can interfere with informational access and, consequently, in the decision making of families in relation to child treatment and their rights. Likewise, it is important to look at how health professionals are managing these demands, what strategies are adopted and professional perspectives in view of the various technological possibilities, especially in Brazil.

\section{CONCLUSION}

The sources of information used by families demonstrate a new demand on professionals, in order to integrate the use of knowledge from different sources, in the health care process. The preparation of family members to exercise criticality in the data accessed becomes important for health professionals and managers to consider the benefits and weaknesses that this represents in people's health. Reports freely available must be assessed for reliability. Access to information from non-formal sources does not replace the guidance of a qualified professional in the area of ASD.

This study provides a theoretical basis for professional performance in care and includes guidance on access to information; contributes with theoretical support for the implementation of public policies involving informational support; likewise, it offers new perspectives to be explored in future studies.

As a limitation of the present research, the participants were mainly mothers who were accompanying the child at the study site. A fact that does not compromise its quality and authenticity, however, it is believed that the perspective of other family members could enrich its findings. A second limitation is the study design, in which only family members were included, and not the professionals and managers who serve the population studied. The perspective of these professionals can bring other perspectives about the thematic of this work. 


\section{REFERENCES}

1. Baio JB, Wiggins L, Christensen D, Maenner MJ, Daniels J, Warren Z, et al. Prevalence of autism spectrum disorder among children aged 8 years Autism and Developmental Disabilities Monitoring Network, 11 sites, United States, 2014. MMWR Surveill Summ. 2018;67(6):1-23. doi: https://doi. org/10.15585/mmwr.ss6706a1

2. American Psychiatric Association. DSM-5: Manual diagnóstico e estatístico de transtornos mentais. Porto Alegre: Artmed Editora; 2014.

3. Dinora P, Bogenschutz M. Narratives on the factors that influence family decision making for young children with autism spectrum disorder. J Early Interv. 2018 Sep;40(3):195-211. doi: https://doi.org/10.1177/1053815118760313

4. James HS. Stress, Social Support, and Health: Theoretical foundations. 1981.

5. Mesquita JARD. Suporte social e redes de apoio social em idosos [dissertação]. Alfama: Instituto Superior de Psicologia Aplicada; 2011 [cited 2020 Jan 10]. Available from: http://repositorio.ispa.pt/bitstream/10400.12/3863/1/7260.pdf

6. Machado MS, Londero AD, Pereira CRR. Becoming the family of a child with Autistic Spectrum Disorder. Contextos Clín. 2018;11(3):335-50. doi: https://doi. org/10.4013/ctc.2018.113.05

7. Hodgetts S, Zwaigenbaum L, Nicholas D. Profile and predictors of service needs for families of children with autism spectrum disorders. Autism. 2015 Jul;19(6):673-83. doi: https://doi.org/10.1177/1362361314543531

8. Mcintyre LL, Brown M. Examining the utilisation and usefulness of social support for mothers with young children with autism spectrum disorder. I Intellect Dev Disabil. 2016 Nov;43(1):93-101. doi: https://doi.org/10.3109/13668250.2016.1262534

9. Roffeei SHM, Abdullah N, Basar SKR. Seeking social support on Facebook for children with Autism Spectrum Disorders (ASDs). Int J Med Inform. 2015;84(5):375-85. doi: https://doi.org/10.1016/j.jjmedinf.2015.01.015

10. Edwards AG, Brebner CM, McCormack PF, MacDougall CJ. From 'parent'to 'expert': how parents of children with Autism Spectrum Disorder make decisions about which intervention approaches to access. J Autism Dev Disord. 2018 Jun;48(6):2122-38. doi: https://doi.org/10.1007/s10803-018-3473-5

\section{- Acknowledgment:}

To the National Council for Scientific and Technological Development, Ministry of Technology, Science and Information for the resources obtained by the Universal Project approved by the call MCTI/CNPq No. 01/2016.
11. Bardin, L. Análise de conteúdo. 4. ed. Lisboa: Edições 70; 2010.

12. Grant N, Rodger S, Hoffmann T. Intervention decision-making processes and information preferences of parents of children with autism spectrum disorders. Child Care Health Dev. 2016 0ct;42(1):125-34. doi: https://doi.org/10.1111/ cch. 12296

13. Hays A, Butauski M. Privacy, disability, and family: exploring the privacy management behaviors of parents with a child with autism. West J Commun. 2018;82(3):376-91. doi: https://doi.org/10.1080/10570314.20 17.1398834

14. Liu Y, Fisher K. Engaging with disability services: experiences of families from Chinese backgrounds in Sydney. Australian Soc Work. 2017 Jun;70(4):441-52. doi: https://doi.org/10.1080/0312407X.2017.1324885

15. Wallace $L R$. The impact of family autism camp on families and individuals with ASD. The Qualitative Report. 2016 [cited 2020 Feb 25];21(8):1441-53. Available from: https://nsuworks.nova.edu/tqr/vol21/iss8/8/

16. Tait K, Fung F, Hu A, Sweller N, Wang W. Understanding Hong Kong Chinese families' experiences of an autism/ASD diagnosis. J Autism Dev Disord. 2016 Nov;46(4):1164-83. doi: https://doi.org/10.1007/s10803-015-2650-z

17. Risling T, Risling D, Holtslander L. Creating a social media assessment tool for family nursing. J Fam Nurs. 2017;23(1):13-33. doi: https://doi. org/10.1177/1074840716681071

18. Lima VF, Mazza VA. Information needs of families on the health/ disease of preterm infants in a neonatal intensive care unit. Texto Contexto Enferm. 2019;28:e20170474. doi: https://doi. org/10.1590/1980-265x-tce-2017-0474

19. Schroeder WK. Leveraging social media in \#FamilyNursing Practice. J Fam Nurs. 2017;23(1):55-72. doi: https://doi.org/10.1177/1074840716684228

20. Hall CM, Culler ED, Frank-Webb A. Online dissemination of resources and services for parents of children with Autism Spectrum Disorders (ASDs): a systematic review of evidence. J Autism Dev Disord. 2016 Dec;3(4):273-85. doi: https://doi.org/10.1007/s40489-016-0083-z

\section{- Corresponding author:}

Gisele Weissheimer

E-mail: gisele.weissheimer@gmail.com

\section{Associate editor:}

Cíntia Nasi

Received: 04.03.2020

Editor-in-chief:

Approved: 08.04.2020

Maria da Graça Oliveira Crossetti 